\title{
Aspek Agronomi Pohon Karet dan Masalah yang Dihadapi Petani Karet
}

\author{
Sumihar Hutapea*, Ellen L. Panggabean, Rizal Aziz, Tumpal HS Siregar, Suswati \\ Program Studi Agroteknologi, Fakultas Pertanian, Universitas Medan Area, Percut Sei Tuan, Deli Serdang, \\ Sumatera Utara, Indonesia
}

Submisi: 14 Desember 2019; Revisi: 22 Juni 2020; Penerimaan: 24 Juni 2020

Kata Kunci:
Jamur akar
putih
Produksi
rendah
Sadap

\begin{abstract}
Abstrak Tebal kulit disadap, kedalaman sadap, panjang alur sadap, frekuensi sadap, dan waktu sadap harus dipertimbangkan dalam penyadapan pohon karet. Perencanaan penggunaan bidang sadap penting untuk menjamin periode sadap yang panjang, lebih dari 25 tahun. Pada perkebunan karet rakyat hal tersebut tidak dianut. Oleh karena itu, penyuluhan yang sesuai dengan kebutuhan petani diperlukan. Penelitian ini menyajikan aspek agronomi perkebunan karet rakyat yang menunjukkan rendahnya produksi dan beberapa aspek penyuluhan yang diperlukan petani karet. Penelitian dilakukan melalui survei dan tanya jawab pada Juni-Juli 2019 di Desa Sari Laba Jahe, Kecamatan Biru-Biru, Kabupaten Deli Serdang, Provinsi Sumatera Utara. Kelompok yang disurvei adalah Kelompok Tani Mekar Tani yang beranggota 30 orang. Pengumpulan data dilakukan dengan pengamatan kebun karet masing-masing petani dan tanya jawab untuk memperoleh data serta informasi, berkaitan dengan aspek agronomi. Hasil penelitian menunjukkan bahwa petani karet belum menghasilkan produksi ideal, 26,67\% petani menghasilkan kurang dari $25 \mathrm{~g}$ per pohon per sadap. Sebanyak 17 petani mengelola kebun seluas kurang dari 1 ha dan 1-1,5 ha mengelola kurang dari 500 pohon per ha. Sebanyak $46 \%$ petani berpendapat bahwa masalah yang dihadapi dalam mengelola kebun karetnya
\end{abstract} adalah penyakit jamur akar putih (JAP).

Keywords:

Low production tapping

White root fungus
Abstract The bark thickness, tapping depth, tapping groove length, tapping frequency, and tapping time should be considered in the tapping of a rubber tree. Planning the use of tapping fields is important to guarantee a long-tapping period, which is more than 25 years. However, in smallholder rubber plantations, this is often not adopted. Therefore, counseling according to farmer's needs is still needed. This research presents the agronomic aspects of smallholder rubber plantations as an indication of the low production of smallholder rubber and several aspects of counseling that are needed by rubber farmers. The research method used was in the form of survey, questions and answers conducted in June-July 2019, located in Sari Laba Jahe Village, Biru-Biru District, DeliSerdang Regency, North Sumatra Province. The farmer groups surveyed are 30 members of the Mekar Tani Farmers Group. Data collection was carried out by observing each rubber farmer and asking question to obtain some data and information related to agronomic aspects. Based on this study it was concluded that rubber farmers in the Mekar Tani Group, Sari Laba Jahe Village, Biru-Biru District, Deli Serdang Regency, North Sumatra Province have not produced an ideal production, ie $26.67 \%$ of farmers produce less than 25 grams per tree per tapping. A total of 17 farmers who manage an area of less than 1 ha and in the range of 1 to 1.5 ha manage less than 500 plants per ha. As many as $46 \%$ of

ISSN 2460-9447 (print), ISSN 2541-5883 (online)

${ }^{*}$ Corresponding author: Sumihar Hutapea

Program Studi Agroteknologi, Fakultas Pertanian, Universitas Medan Area, Jln. Kolam No. 1 Medan Estate, Kelnangan Baru, Percut Sei Tuan, Deli Serdang 20223, Sumatera Utara, Indonesia

Email: sumihutapeal@gmail.com 


\section{PENDAHULUAN}

Desa Sari Laba Jahe merupakan salah satu desa di Kabupaten Deli Serdang, Sumatera Utara. Desa tersebut dapat dijangkau dengan perjalanan sekitar satu jam menggunakan mobil. Para petani karet di Sari Laba Jahe tergabung dalam Kelompok Mekar Tani. Mereka secara konsisten tetap menghasilkan karet meskipun harganya rendah sehingga mereka termasuk petani yang memperoleh pendapatan lebih tinggi daripada petani di desa penghasil karet lainnya di Kabupaten Deli Serdang (Badan Pusat Statistik Deli Serdang, 2019).

Penelitian ini bertujuan untuk mengetahui kondisi penyadapan pohon karet pada Kelompok Mekar Tani di Kabupaten Deli Serdang, Provinsi Sumatera Utara yang meliputi mutu penyadapan dan mutu penanganan hasil, serta mengetahui aspek apa yang dibutuhkan untuk diseminasi teknologi budidaya karet.

Dalam skala kebun, umur pohon dan jumlah pohon per satuan sadap yang disebut hanca sadap merupakan aspek manajemen produksi pada perkebunan karet. Pada perusahaan perkebunan, hal ini dilakukan dengan menerapkan baku jumlah pohon yang disadap setiap hari. Pemeliharaan pohon yang meliputi pemupukan dan pengendalian penyakit, terutama penyakit pada kulit, seperti mati kulit (bark necrosis), kering alur sadap, jamur akar putih, dan penyakit pada daun menjadi unsurunsur pendukung terpenuhinya jumlah pohon yang menghasilkan lateks (Siagian et al., 2010).

Perkebunan rakyat di Indonesia belum menerapkan konsep dasar tersebut, sebagaimana dilaporkan Viswanathan (2012) dan Siagian et al. (2010). Penyadapan pada pohon karet masih dianggap sebagai usaha pelukaan kulit tanpa mempertimbangkan integrasi aspek-aspek di atas (Aliyu et al., 2017). Hal ini menyebabkan produksi karet rakyat di Indonesia rendah, yaitu kurang dari $800 \mathrm{~kg} / \mathrm{ha} / \mathrm{tahun}$ (Sumarmadji \& Junaidi, 2010). Produksi yang rendah secara umum tercermin dari kondisi agronomi kebun, yaitu jumlah pohon per hektar, umur pohon, frekuensi sadap, dan sejumlah aspek lain.

Harga karet pada lebih dari 10 tahun terakhir rendah sehingga para petani tidak memperoleh pendapatan yang memadai dari pengelolaan kebunnya (Tongkaemkaew \& Chambon, 2018; Otten et al., 2020). Pada banyak kebun karet, hal ini mengakibatkan para petani tidak melakukan pemeliharaan dan penyadapan untuk menghasilkan karet. Akan tetapi, petani dalam Kelompok Mekar Tani masih terus melakukan penyadapan meskipun produksinya rendah, yaitu pada kisaran 25-50 gram/pohon/sadap. Jumlah produksi ini masih sangat rendah karena idealnya jumlah produksi mencapai kisaran di atas 85 gram per pohon per sadap (Chambon et al., 2013). Untuk meningkatkan produksi dan pendapatan diperlukan identifikasi masalah yang dihadapi, baik dalam aspek agronomi maupun kebutuhan para petani, untuk menetapkan prioritas penyuluhan yang diperlukan dan berhubungan dengan pengelolaan kebun karet (Syarifa, 2012).

Penyadapan pohon karet sangat dipengaruhi oleh teknik penyadapan yang merupakan perpaduan antara keterampilan dan kesinambungan produksi. Tebal kulit yang disadap dan kedalaman sadap adalah hal yang harus dipertimbangkan. Panjang alur sadap, frekuensi sadap, dan waktu sadap juga harus dipertimbangkan (Siagian $e t$ al., 2010). Dari aspek manajemen, perencanaan penggunaan bidang sadap menjadi hal penting untuk menjamin periode sadap yang panjang, yaitu lebih dari 25 tahun (Aliyu et al., 2017). Dari aspek peralatan, jenis dan mutu pisau sadap harus sesuai dengan kebutuhan penyadapan periodik sehingga penyadapan dilakukan dengan mengacu pada baku yang diberlakukan, yaitu pelukaan periodik pada kulit pohon. Pada perkebunan karet rakyat, pelukaan periodik yang sesuai dengan baku penyadapan sering tidak dianut (Ogbebor \& Osahon, 2013). Dengan demikian, produksi pada setiap kali penyadapan rendah, umur ekonomi pohon singkat, dan kulit sebagai modal utama untuk memproduksi lateks mengalami pertumbuhan yang tidak dapat lagi disadap (Sainoi \& Doodee, 2012).

\section{METODE PELAKSANAAN}

Penelitian dilakukan di Desa Sari Laba Jahe, Kecamatan Biru-Biru, Kabupaten Deli Serdang, Provinsi Sumatera Utara. Petani yang terlibat berjumlah 30 orang, yaitu petani yang berkenan dari 42 anggota kelompok tani. Desa tersebut dipilih berdasarkan jaraknya yang dekat dari Kota Medan, yaitu hanya $35 \mathrm{~km}$, sehingga paling mudah diakses. Pengumpulan data dilakukan dengan mengamati aspek agronomi pada kebun karet masingmasing petani. Pengisian kuesioner dilakukan untuk memperoleh data dan informasi yang berkaitan dengan aspek agronomi serta masalah utama yang dihadapi dalam mengelola kebun karet. Data dan informasi yang diperoleh kemudian dikompilasi dan diklasifikasi menurut parameter luas kebun yang disadap, umur pohon, produksi, pengalaman mengelola kebun karet, dan masalah yang dihadapi. Data dianalisis dengan mengelompokkan jawaban petani. Data disajikan dalam persentase. 


\section{HASIL DAN PEMBAHASAN}

\subsection{Luas kebun yang dikelola}

Data yang diperoleh menyebutkan bahwa bahwa $70 \%$ petani mengelola kebun karet dengan luas di bawah 1 ha. Informasi yang diperoleh juga menunjukkan bahwa $13,33 \%$ petani mengelola kebun karet dengan luas lebih dari 2 ha dan 6,66\% petani mengelola kebun karet dengan rentang luas 1,5-2 ha. Sepuluh persen petani mengelola kebun karet dengan rentang luas 1-1,5 ha berjumlah (Gambar 1). Berdasarkan sebaran tersebut diketahui bahwa produksi yang memadai untuk memperoleh pendapatan ideal pada saat harga karet rendah terutama dengan penyadapan dan pengelolaan produksi yang tidak menganut asas baku, seperti penyadapan sedini mungkin, penyadapan dari arah kiri atas ke kanan bawah, belum digunakannya pisau sadap standar, tebalnya kulit yang disadap, dan belum digunakannya stimulan, tidak akan tercapai dengan luas pengelolaan kebun yang kurang dari 1 ha.

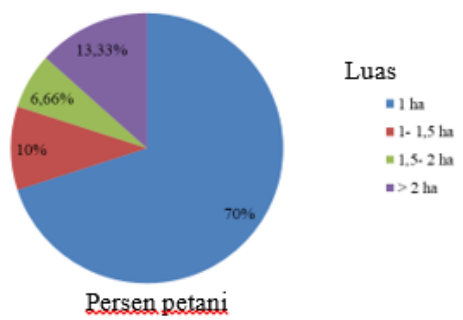

Gambar 1. Sebaran luas kebun yang dikelola petani karet

Pada penelitian ini luas kebun yang disadap tidak disertai dengan konsistensi jumlah pohon per hektar. Dengan kata lain, luas kebun yang dikelola tidak mencerminkan jumlah pohon per hektar yang ideal sehingga produksi yang diperoleh tidak berkorelasi positif dengan luas kebun (Viswanathan, 2012 \& Parichatnon et al., 2017). Hasil pengamatan di kebun petani menunjukkan bahwa teknik penyadapan yang sembarangan menyebabkan produksi tidak berkorelasi positif dengan jumlah pohon yang disadap pada setiap hari sadap. Tabel 1 menunjukkan bahwa luas kebun tidak mencerminkan jumlah pohon yang ideal.

Tabel 1. Jumlah pohon karet menurut luas

\begin{tabular}{lcccc}
\hline \multicolumn{1}{c}{$\begin{array}{c}\text { Jumlah } \\
\text { Tanaman }\end{array} \quad$ Pohon) } & ha & ha & ha & ha \\
\cline { 2 - 5 } \multicolumn{1}{c}{$\quad<1$} & $1-1,5$ & $1,5-2$ & $>2$ \\
$<500$ & 15 & 2 & & \\
$500-700$ & 4 & 1 & & \\
$>700$ & 2 & & & \\
900 & & & 1 & \\
1400 & & & 1 & \\
1500 & & & & 1 \\
$>1500$ & & & & 3 \\
\hline Jumlah Petani & 21 & 3 & 2 & 4 \\
\hline
\end{tabular}

Tabel 1 menunjukkan bahwa dalam kelompok luas 1 ha, 15 petani mengelola kurang dari 500 pohon; 4 petani mengelola pohon dengan rentang 500-700 pohon; dan 2 petani mengelola lebih dari 700 pohon. Petani yang mengelola kurang dari 500 pohon per hektar juga tidak dapat menaikkan produksi yang diperoleh tanpa perubahan sistem penyadapan. Hal yang sama juga dialami oleh kelompok lainnya. Dengan demikian, luas yang tidak memenuhi jumlah pohon per hektar menyebabkan produksi tetap rendah.

Agar produksi yang diperoleh memadai, baku jumlah pohon yang disadap idealnya 500 pohon per hektar (Siagian et al., 2010). Teknik penyadapan yang baru dibutuhkan untuk menaikkan produksi bila jumlah pohon yang disadap tidak mencapai 500 pohon per ha. Teknik penyadapan baru itu antara lain double cut, penggunaan stimulan, atau penyadapan bidang sadap atas dengan menggunakan pisau sadap khusus (H0-1 dan H02). Fakta dalam penelitian ini merupakan hal umum yang ditemukan pada perkebunan karet rakyat di Indonesia, khususnya saat harga karet rendah sejak 2012. Petani karet tidak melakukan intensifikasi penyadapan dan pemeliharaan kebun karena tidak menganut baku penyadapan, yaitu konsistensi tebal kulit yang disadap, penyadapan dari arah kiri atas ke kanan bawah, penyadapan sedini mungkin, penyadapan sesuai dengan bidang sadap, dan penggunaan stimulan (Sainoi \& Doodee, 2012). Selain itu, mereka juga tidak menggunakan pisau sadap yang ideal (Gambar 2) serta tidak mengelola kebun yang benar, seperti tidak melakukan pengendalian gulma pada gawangan dan penyakit pada bidang sadap, serta pemupukan periodik (Siagian et al., 2010). Berdasarkan penelitian yang dilakukan Sumarmadji \& Junaidi (2010) diketahui bahwa jumlah pohon per hektar dan jumlah pohon yang disadap setiap hari sadap menjadi unsur penting untuk menghasilkan produksi yang tinggi pada setiap hari sadap. Apabila penyadapan dilakukan dengan teknik yang benar pada dasarnya luas kepemilikan lahan bukan lagi menjadi komponen penting.

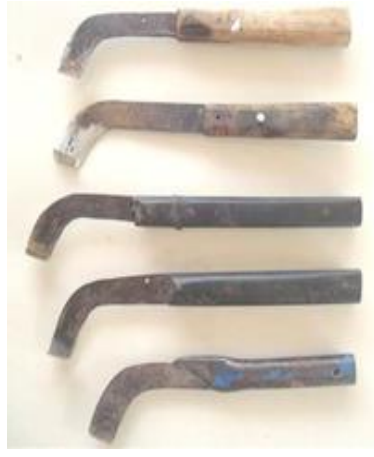

(A)

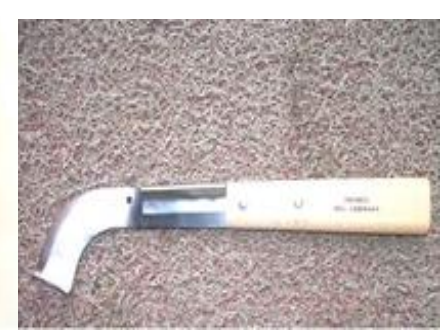

(B)
Gambar 2. (A) Jenis pisau sadap yang digunakan petani dan (B) Pisau sadap standar 
Pengamatan terhadap kebun karet menunjukkan kinerja penyadapan rendah, yang ditandai dengan kerusakan pada kulit pohon (Gambar 3).

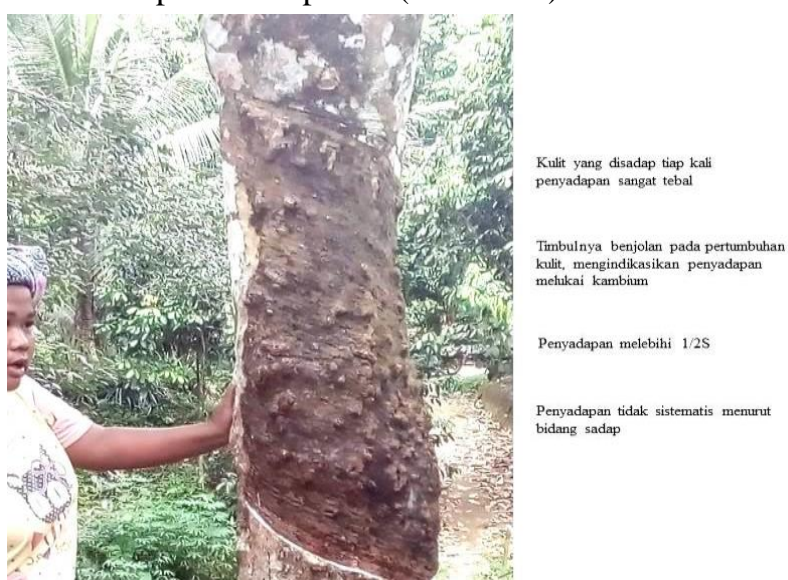

Gambar 3. Mutu kulit pohon karet para petani anggota Kelompok Mekar Tani

\subsection{Umur pohon yang disadap}

Salah satu aspek agronomi yang penting dalam menaikkan produksi pohon karet adalah umur pohon (Directorate of Rubber Plantations, 2001). Penyadapan seharusnya dilakukan sesuai bidang-bidang sadap tertentu dalam kurun waktu tertentu, yaitu bidang sadap yang dimulai dari B0-1 (setengah spiral pada kiri bawah), kemudian dilanjutkan ke B0-2 (setengah spiral pada kanan bawah), lalu dikombinasikan menyadap bidang bidang B1-1 + H0-1 (kulit pulihan pada kiri bawah produksi dan bidang sadap kiri atas), dan B1-2 + H0-2 (kulit pulihan pada kanan bawah dan bidang sadap kanan atas). Pengamatan di lapangan menunjukkan bahwa hal tersebut tidak dilakukan sehingga posisi penyadapan tidak memberi informasi umur pohon.

Hasil wawancara dengan para petani menunjukkan bahwa $41,67 \%$ petani menyadap pohon karet yang telah berumur 10-17 tahun, yaitu rentang umur pohon karet yang pada dasarnya akan menghasilkan produksi tertinggi apabila diterapkan sistem penyadapan yang ideal. Jika didasarkan pada umur pohon, Kelompok Mekar Tani seharusnya dapat menghasilkan produksi yang tinggi (Tabel 2), namun fakta menunjukkan bahwa produksi yang dinilai dalam satuan gram/ pohon/ penyadapan masih rendah. Penyebab rendahnya produksi terutama karena penyadapan tidak menuruti sistem bidang sadap yang seharusnya disadap menurut umur, yaitu dimulai pada bidang sadap B0-1 selama 5-6 tahun, dilanjutkan dengan bidang sadap B0-2 selama 5-6 tahun, dan pada tahun berikutnya disadap dengan mengkombinasikan bidang sadap $\mathrm{H} 0-1$ dan B1-1 serta H0-2 dan B1-2. Di kebun, penyadapan dilakukan tidak menuruti sistem tersebut, demikian juga arah penyadapan yang seharusnya dari kiri atas ke kanan bawah tetapi dilaksanakan dengan sesuka petani, sepanjang mengalirkan lateks. Kulit yang disadap juga tebal, yaitu
$>$ 2,5 mm. Hal ini menyebabkan produksi rendah dan umur ekonomi tanaman singkat.

Tabel 2. Jumlah pohon karet menurut luas (Sumarmadji dan Junaidi, 2010)

\begin{tabular}{|c|c|c|c|}
\hline \multirow[t]{2}{*}{ Klon } & \multirow[t]{2}{*}{ Kepanjangan } & \multicolumn{2}{|c|}{$\begin{array}{c}\text { Produksi } \\
\text { (gram/pohon/sadap) }\end{array}$} \\
\hline & & $1 / 2 \mathrm{~S} \mathrm{~d} / 2$ & $1 / 2 \mathrm{~S} \mathrm{~d} / 3$ \\
\hline ВРМ 24 & $\begin{array}{l}\text { Balai Penelitian } \\
\text { Medan } 24\end{array}$ & 27 & 28 \\
\hline BPM 107 & $\begin{array}{l}\text { Balai Penelitian } \\
107\end{array}$ & 27 & 54 \\
\hline ВРМ 109 & $\begin{array}{c}\text { Balai Penelitian } \\
109\end{array}$ & 28 & 60 \\
\hline PB 217 & Prang Besar 217 & 30 & 55 \\
\hline PB 260 & Prang Besar 260 & 21 & 35 \\
\hline PR 255 & Pusat Riset 255 & 33 & 40 \\
\hline PR 261 & Pusat Riset 261 & 29 & 42 \\
\hline IRR 104 & $\begin{array}{l}\text { Indonesia Rubber } \\
\text { Research } 104\end{array}$ & 60 & 70 \\
\hline IRR 107 & $\begin{array}{l}\text { Indonesia Rubber } \\
\text { Research } 107\end{array}$ & 40 & 49 \\
\hline AVROS & Algemeene & 33 & 57 \\
\hline 2037 & $\begin{array}{c}\text { Vereeniging van } \\
\text { Rubberplanters ter } \\
\text { Oostkusst van } \\
\text { Sumatera } 2037\end{array}$ & & \\
\hline BPM 1 & $\begin{array}{c}\text { Balai/Pusat } \\
\text { Penelitian } \\
\text { Perkebunan } \\
\text { Medan } 1\end{array}$ & 22 & 28 \\
\hline PB 330 & Prang Besar 330 & 36 & 44 \\
\hline RRIC 100 & $\begin{array}{l}\text { Rubber Research } \\
\text { Indonesia Clone } \\
100\end{array}$ & 33 & 40 \\
\hline
\end{tabular}

Sebanyak $4,17 \%$ petani menyadap pohon yang umurnya lebih dari 30 tahun, yaitu umur pohon karet yang tidak produktif lagi sehingga pengenalan sistem penyadapan yang ideal pada petani tersebut tidak memberikan manfaat untuk menaikkan produksi (Tabel 3).

Tabel 3. Distribusi umur pohon karet yang dikelola petani

\begin{tabular}{ccc}
\hline Umur Pohon (tahun) & Jumlah Petani & \% Petani \\
\hline$<10$ & 7 & 29,17 \\
$10-17$ & 10 & 41,67 \\
$17-30$ & 6 & 25,00 \\
$>30$ & 1 & 4,17 \\
\hline & 24 & 100,00
\end{tabular}

Sebanyak 46,67\% petani sudah menggunakan bahan tanam okulasi yang sesuai dengan ketentuan bahan tanam. Aspek agronomi ini menjadi dasar untuk memperoleh produksi yang memadai apabila disertai dengan sistem penyadapan yang benar (Ogbebor \& Osahon, 2013). Sebanyak 30\% petani, yaitu yang mengelola kebun seluas 1 hektar masih menggunakan bahan tanam biji (Tabel 4). Pada penelitian ini secara umum petani sudah mengelola bahan tanam yang 
diperoleh dengan cara yang benar, yaitu okulasi (Syarifa, 2012).

Tabel 4. Sumber bahan tanam petani dengan lahan seluas 1 ha

\begin{tabular}{lr}
\hline Sumber Bahan Tanam & \% Petani \\
\hline Biji & $30 \%$ \\
Okulasi & $46,67 \%$ \\
Tidak Tahu & $23,33 \%$ \\
\hline
\end{tabular}

\subsection{Produksi}

Hasil pengamatan dan perhitungan menunjukkan bahwa sebanyak $26,67 \%$ petani hanya memperoleh produksi kurang dari $25 \mathrm{~g}$ per pohon per sadap dan $20 \%$ petani memperoleh lebih dari 55 g per pohon per sadap (Tabel 5). Perolehan produksi tersebut menunjukkan bahwa usaha peningkatan produksi belum dilakukan melalui sistem penyadapan yang benar dan ideal, yaitu dimulai dari bidang sadap B0-1, arah penyadapan dari kiri atas ke kanan bawah, tiap kali penyadapan hanya mengiris kulit setebal $<1,75 \mathrm{~mm}$, waktu penyadapan sebelum pukul $11.00 \mathrm{WIB}$, digunakannya pisau sadap standar dan setiap 3-4 kali penyadapan harus diasah dan digunakannya stimulan produksi bila pohon sudah $>15$ tahun disadap. Hal-hal tersebut tidak ditaati oleh petani karet dalam Kelompok Mekar Tani. Uraian Siagian et al. (2010) dan Aliyu et.al (2017) menunjukkan bahwa faktor pelatihan keterampilan dan konsistensi terhadap pelaksanaan penyadapan baku merupakan penentu perolehan produksi selain penerapan sistem penyadapan baru.

Tabel 5. Produksi yang dihasilkan petani

\begin{tabular}{ccc}
\hline $\begin{array}{c}\text { Produksi per pohon per } \\
\text { sadap }(\mathrm{g})\end{array}$ & $\begin{array}{c}\text { Jumlah } \\
\text { petani }\end{array}$ & $\%$ \\
\hline$<25$ & 8 & 26,67 \\
$26-35$ & 4 & 13,33 \\
$36-45$ & 7 & 23,33 \\
$46-55$ & 5 & 16,67 \\
$>55$ & 6 & 20,00 \\
& 30 & 100,00 \\
\hline
\end{tabular}

\subsection{Masalah utama yang dihadapi}

Dari hasil wawancara dengan para petani disimpulkan bahwa $100 \%$ petani karet tidak pernah memperoleh bimbingan dan penyuluhan perihal prinsip penyadapan serta kaitan antara pemeliharaan pohon dengan produksi maupun aspek agronomi lainnya. Petani hanya menerapkan pendekatan pengirisan kulit yang meneteskan lateks tanpa mempertimbangkan aspekaspek baku penyadapan. Secara khusus, $46 \%$ petani menyatakan bahwa jamur akar putih (JAP) merupakan masalah utama yang dihadapi. Serangan penyakit tersebut sudah ada yang menyebabkan pohon tumbang. Jamur akar putih merupakan penyakit utama pada pohon karet. Sebanyak $30 \%$ petani menyatakan bahwa mati kulit merupakan masalah utama. Mati kulit diketahui merupakan indikasi yang kuat dari penyadapan yang tidak bersistem sehingga pohon tidak mengalirkan lateks (Aliyu et al., 2017). Sebanyak $16 \%$ petani menyatakan bahwa faktor harga adalah penyebab kebun karet mereka tidak lagi memberikan pendapatan yang layak. Dua persen petani menyatakaan bahwa masalah yang dihadapi adalah rendahnya produksi (Gambar 4).

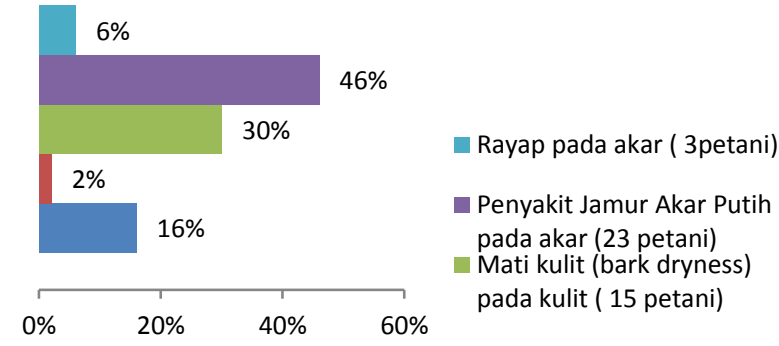

Gambar 4. Kompilasi masalah yang dihadapi petani

\section{KESIMPULAN}

Para petani karet dalam Kelompok Mekar Tani, di Desa Sari Laba Jahe, Kecamatan Biru-Biru, Kabupaten Deli Serdang, Sumatera Utara mengelola kebun karet yang belum mampu memproduksi jumlah karet yang ideal. Sebanyak 26,67\% petani menghasilkan kurang dari $25 \mathrm{~g}$ per pohon per sadap. Selain itu, 17 petani yang mengelola kebun kurang dari 1 ha serta pada kisaran 1-1,5 ha mengelola kurang dari 500 pohon per ha. Secara umum petani belum menerapkan baku agronomi. Sebanyak $46 \%$ petani menyatakan bahwa penyakit JAP masih menjadi masalah utama, diikuti oleh $30 \%$ petani yang menyatakan bahwa mati kulit sebagai masalah dalam penyadapan.

\section{UCAPAN TERIMA KASIH}

Penulis mengucapkan terima kasih kepada Direktorat Penelitian dan Pengabdian Masyarakat Kemenristek Dikti dan Kepala LLDIKTI Wilayah I Sumatera Utara yang telah mendukung pendanaan sesuai dengan Surat Keputusan No. 11/K1.1/LT.I/2019 dan Surat Perjanjian Pelaksanaan Penugasan Program Kemitraan Masyarakat No. 571/LP2M/04.6/VII/2019. Ucapan terima kasih juga disampaikan kepada pimpinan Universitas Medan Area yang telah mendukung pelaksanaan kegiatan ini dan seluruh anggota Kelompok Mekar Tani, Desa Sari Laba Jahe, Kecamatan Biru-Biru, Kabupaten Deli Serdang, Provinsi Sumatera Utara yang telah turut berpartisipasi, khususnya kepada Bapak Setia Budi Barus sebagai ketua kelompok tani. 
DAFTAR PUSTAKA

Aliyu,A., Latif,I.A., Shamsudin,M.N., \&Nawi, N.M. (2017). Factors Affecting Technical Efficiency of Rubber Smallholders in Negeri Sembilan. Journal of Malaysia Agricultural Science, 9(5), 226-232. DOI:10.5539/jas.v9n5p226

Badan Pusat Statistik Deli Serdang. 2019. Indikator Kesejahteraan Rakyat Kabupaten Deli Serdang 2019. p.70.

Chambon,B.,S.Angthong.,C.Kongmanee, B., Somboonsuke., S.Mazon., A. Puengcharoen., C.Martin., \& R.Lacote. (2013). A Comparative Analysis of Smallholders Tapping Practices in Four Rubber Producing Regions of Thailand. Dalam C.Nakason., A.Thitithammawong, \& S. Wisunthorn (Eds). Advanced Materials Research, 844, 34-37. DOI: https://doi.org/10.4028/www.scientific.net/AMR8 44.34

Directorate of Rubber Plantations Cambodia. (2001). Smallholders Rubber Developmentin Kompong Cham Province, ppt.33p.

Otten, F.,J.Hein, H.Bondy., \& H.Faust. (2020). Deconstructing Sustainable Rubber Production: Contesting Narratives in Rural Sumatra. Journal of Land Use Science. DOI: 10.1080/1747423X.2019.1709225

Ogbebor, O.O. \& Osahon, O. (2013). The Sustainability of Agriculture in Nigeria Using

Rubber as a Case Study (Electronic Thesesand Dissertations, Paper 2312). Diakses dari http://dc.etsu.edu/etd/2312

Parichatnon, S., Maichum, K., \& Peng, K. (2017). Application of Data Envelopment Analysis and Malmquist Index on the Measurement of Efficiency and Productivity: A Case Study of Rubber Production in Southern Thailand. PEOPLE: International Journal of Social Sciences, 3(2), 775-786. DOI: https://dx.doi.org/10.20319/pijss.2017.32.775786

Sainoi, T.\& Doodee,S. (2012). The Impactof Ethylene Gas Applicationon Young-Tapping Rubber Trees. Journal of Agricultural Technology, 8(4), 14971507. http://www.ijat-aatsea.com

Siagian, N., Tumpal, H.S.S., Sumarmadji, \& Karyudi. (2010). Potret Umum Pelaksanaan Norma Baku Eksploitasi di Beberapa Perkebunan Karet. Kumpulan Makalah Workshop Eksploitasi, p.24.

Sumarmadji \& Junaidi. (2010). Sistem Eksploitasi Pohon Karet Berdasarkan Tipologi Klon (Quickand Slow Starter). Balai Penelitian Sungei Putih. Pusat Penelitian Karet.

Syarifa, L.F. (2012). Evaluasi Tingkat Adopsi Klon Unggul di Tingkat Petani Karet Propinsi Sumatera Selatan. Jurnal Penelitian Karet, 30(1), 12-22. DOI: https://doi.org/10.22302/ppk.jpk.v30i1.118

Tongkaemkaew,U.\&B. Chambon. (2018). Rubber Plantation Labor and Labor Movements as Rubber Prices Decrease in Southern Thailand. Forest and
Society,
2(1),
$18-27$.
DOI: http://dx.doi.org/10.24259/fs.v2i1.3641

Viswanathan, P.K. (2012). Emerging Smallholder Rubber Farming Systems in India and Thailand: A Comparative Economic Analysis. Asian Journal of Agriculture and Development, 5(2), p.1-20. DOI: 10.22004/ag.econ.198984 